\title{
Gender, Employment, and Domestic and External Savings in Guatemala
}

\author{
Luis René Cáceres \\ ${ }^{1}$ Independent Researcher, El Salvador; A Luis Rene Samuel Atilio, mi hijo, con amor salvadoreño \\ Correspondence: Luis Rene Caceres, 5456 Paseo General Escalon, San Salvador, El Salvador. E-mail: \\ luisrenecaceres@gmail.com
}

Received: March 30, 2021

Accepted: May 23, 2021

Online Published: May 30, 2021

doi:10.5539/ijef.v13n6p165

URL: https://doi.org/10.5539/ijef.v13n6p165

\begin{abstract}
.
The objective of this paper is to analize the role, for the case of Guatemala, that the ratio of female to male employment plays in the mobilization of internal savings, in the trade deficit, as well as in the economic growth constrained by the balance of payments model. The results indicate that said ratio increases savings, reduces the deficit in the trade account and eases the balance of payments constraint on economic growth. It is recommended that Guatemalan authorities undertake extraordinary measures to encourage female participation. The originality of the paper resides in being the first one to highlight the role of the ratio of female to male employment on the reduction of the deficit in the trade account and in showing that this ratio can constitute a constraint to economic growth. The paper concludes stressing the importance of promoting female participation.
\end{abstract}

Keywords: gender, savings, balance of payments constraint, economic growth, employment, savings gap

\section{Introduction.}

An extensive literature has shown that women have different preferences than men on how they spend their money. The seminal study by Thomas (1992) showed that women are more willing than men to spend their income on improving the nutrition of their childen, while Kumar (1978) presented evidence that the amounts of resources spent on the nutrition of children have a positive correlation with the mother's income and no correlation with the father's income.

Other studies have indicated that women are more prudent and cautious than men in the area of personal finances, which is due to the recognition of their unstable situation in the labor market, since they can be subject to arbitrariness at any time, and because their wages are lower than those earned by men. Hinz, McCarthy, and Turner (1996) reported that women invest in their retirement plans more cautiously than men, while Jianakoplos and Bernasek (1998) reported that when women's wealth increase, their acquisition of risky assets is low relative to that of men.

Of special importance is the work of Seguino and Floro (2003) who have argued that the increase in the income of women relative to that of their husbands, or partners, strengthens their decision-making capacity at home, which leads to an increase in their personal savings and, at the aggregate level, gives rise to an increase in domestic savings in the country in question. These authors estimated equations with panel data for the 1975-1995 period from 70 countries, finding that the increase in female income relative to that of men led to increases in domestic savings.

Agenor, Ozdemir, and Moreira (2018) developed an overlapping generations model to simulate the repercussions of the elimination of the gender gap in salaries, finding that women used the additional income in investments to improve their education, which resulted in subsequent increases in their wages. The point that these authors highlight is that, as a result of their better salaries, women acquire greater decision-making capacity at home, which translates into increases in their personal savings.

Cáceres (2020a) analyzed with a cross section of 2017 data from 17 Latin American countries, the role that the female to male employment ratio plays on domestic savings, finding that this ratio has a positive impact. A similar result was reported by Cáceres (2020b) for the case of Honduras, using data from the 1990-2018 period.

This paper investigates, for the case of Guatemala, the roles that the ratios of female to male employment of different quality, whether self-employment or industrial employment, exert on savings; the paper also analyzes 
the role of these ratios in reducing the trade account deficit of the balance of payments, postulating that, since the employment ratio has a positive role in increasing savings, it will contribute to reducing the internal savings gap, that is, the difference between investment and savings, and therefore, will help reduce external savings.

The results show that the ratio of female to male employment increases domestic savings when this ratio is computed with industrial, agricultural, or service sector employment, but the effect is negative when female and male self-employment values are used. The results also indicate that the increase of the first three ratios tend to reduce the deficit in the trade account. This paper also analyzes the influence of the ratio of female to male employment on economic growth. The work ends with a series of conclusions.

\section{The Data}

The data corresponds to the period 1990-2018 and its source is the World Bank's World Development Indicators. All variables were subjected to unit root tests using the ADF test, with results indicating that all were integrated of order 1 at the 1 percent level, except for the male youth unemployment rate, which turned out to be stationary at that level.

Considering that the equations to be estimated include variables with unit roots, it was decided to carry out the estimations using the Phillips and Hansen (1990) Fully Modified Least Squares methodology.

The average values and standard deviations of the variables are shown in Table 1.

Table 1. Average values and standard deviations of the variables

\begin{tabular}{lcc}
\hline Variable & Average & Standard deviation \\
\hline Domestic savings rate & 6.0548 & 2.624 \\
Female youth unemployment & 6.3526 & 1.3173 \\
Male youth unemployment & 4.113 & 0.3802 \\
Female industrial employment & 21.696 & 3.5977 \\
Male industrial employment & 21.7138 & 1.2192 \\
Female services employment & 64.0916 & 6.243 \\
Male services employment & 32.733 & 3.8773 \\
Female agricultural employment & 14.212 & 2.7965 \\
Male agricultural employment & 45.5531 & 3.3658 \\
Female self employment & 51.5149 & 4.041 \\
Male self employment & 42.5056 & 5.5675 \\
Tariff & 5.804 & 1.7921 \\
\hline
\end{tabular}

Figure 1 shows that Guatemala's domestic savings rate (guahorrodomestico), has expereinced a declining tendency in the period under study, with negative consequences on economic growth.

GUAAHORRODOMESTICO

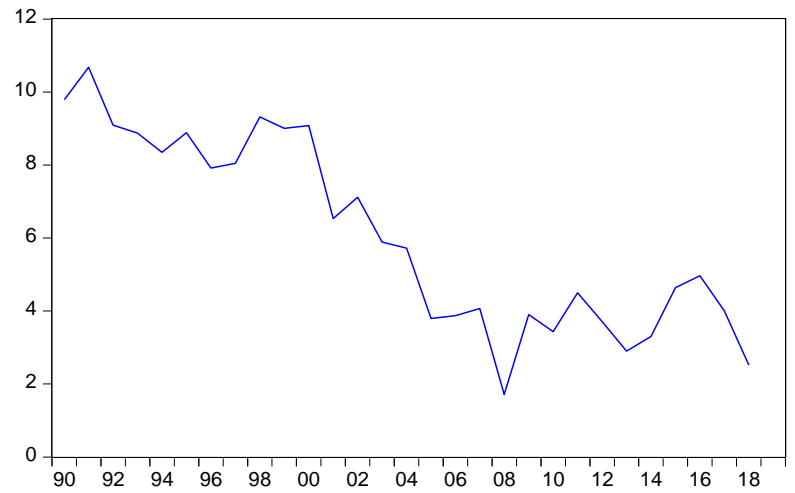

Figure 1. Guatemala's domestic savings rate

\section{Results.}

In its general version, the model to be estimated is:

Domestic savings $=\mathrm{S}$ (female employment $\mathrm{i} /$ male employment $\mathrm{i}$ ), 
Where the index i represent the type of employment, whether industrial, services, agricultural, or self-employment.

A second model postulates that the external savings gap, (imports - exports), depends on investment and the ratio of female to male employment:

External savings gap = B (Investment, female employment i / male employment i), where i represent the type of employment.

The results from the estimated equations are presented in Table 2 (Note 1).

Equation (1) in Table 2 shows that the ratio of female to male industrial employment has a positive and significant coefficient, and the equation explains 45 percent of the variance of the domestic savings rate.

Figure 2 corresponds to this equation, where the employment raio is shown on the $\mathrm{x}$ axis, and the domestic savings rate on the y axis. It is observed in this Figure that this ratio has decreased from 1.17 to 0.68 in the period; consequently, the domestic savings rate has decreased from around 10 percent in the early 1990 s to 2.5 percent in 2018. That is, women have lost employment in the industrial sector relative to men, which has resulted in the fall of savings.

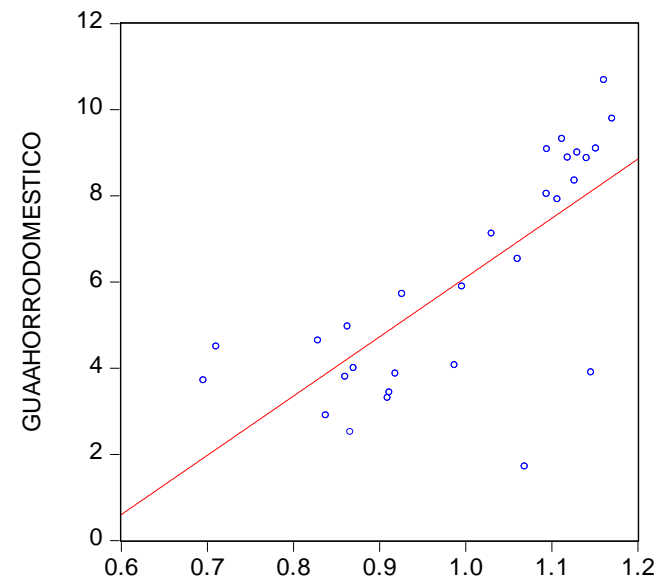

GUAEMPLEOINDUSTRIAFEME/GUAEMPLEOINDUSTRIAMASC

Figure 2. Ratio of Female to Male industrial employment and domestic savings

The coefficient of the ratio of female employment in the service sector to male employment in the same sector is also positive and significant, as can be seen in equation (2), but the R squared is lower than that corresponding to equation (1).

In equation (3) the independent variable is the female to male self-employment ratio, whose coefficient is negative and significant. Self-employment represents employment in the informal sector, so this equation indicates that the greater the presence of women in the informal sector, the lower the savings rate. This is one way through which informality slows economic growth.

Equation (4) shows that the ratio of female to male employment in agriculture has a positive coefficient, indicating that the increase in female relative to male agricultural employment tends to increase the saving rate.

Table 2. Determinants of domestic savings (Dependent Variable: Domestic Savings Rate)

\begin{tabular}{|c|c|c|c|c|c|c|}
\hline \multirow{2}{*}{ Independent variables } & \multicolumn{6}{|c|}{ Equation number: } \\
\hline & (1) & (2) & (3) & (4) & (5) & (6) \\
\hline \multirow[t]{2}{*}{ Constante } & -11.8572 & -45.8204 & 33.7014 & -5.9559 & 13.2203 & -1.7507 \\
\hline & $(3.45)$ & $(4.13)$ & $(2.25)$ & $(2.07)$ & $(4.86)$ & $(0.90)$ \\
\hline \multirow[t]{2}{*}{ Cuali } & & & & -3.7037 & & -3.2727 \\
\hline & & & & $(3.75)$ & & $(2.20)$ \\
\hline Female industrial employment/ & 17.8758 & & & & & \\
\hline Male industrial employment & $(5.21)$ & & & & & \\
\hline Female services employment/ & & 26.2337 & & & & \\
\hline Male services employment & & $(4.65)$ & & & & \\
\hline
\end{tabular}




\begin{tabular}{|c|c|c|c|c|c|c|}
\hline Female self-employment/ & & & -20.8151 & & & \\
\hline Male self-employment & & & $(1.81)$ & & & \\
\hline Female agricultural employment/ & & & & 40.0651 & & \\
\hline Male agricultural employment & & & & $(4.34)$ & & \\
\hline \multicolumn{7}{|l|}{ Female youth unemploynt (-6)/ } \\
\hline \multirow[t]{2}{*}{ Male youth unemployment (-6) } & & & & & -4.8378 & \\
\hline & & & & & $(2.64)$ & \\
\hline \multirow[t]{2}{*}{ Tariff } & & & & & & 1.2622 \\
\hline & & & & & & $(3.68)$ \\
\hline $\mathrm{R}$ squared & 0.45 & 0.28 & 0.24 & 0.17 & 0.54 & 0.56 \\
\hline
\end{tabular}

In equation (5) in Table 2 it is observed that the ratio of female to male youth unemployment, both lagged six years, has a negative and significant coefficient; this means that an increase in female relative to male youth unemployment gives rise to a drop in the savings rate six years later.

It's observed in Figure 3 that in Guatemala the rate of female youth unemployment, (Guadesempleojovenfeme), has been higher than the male rate (guadesempleojovenmasc), throughout the period.

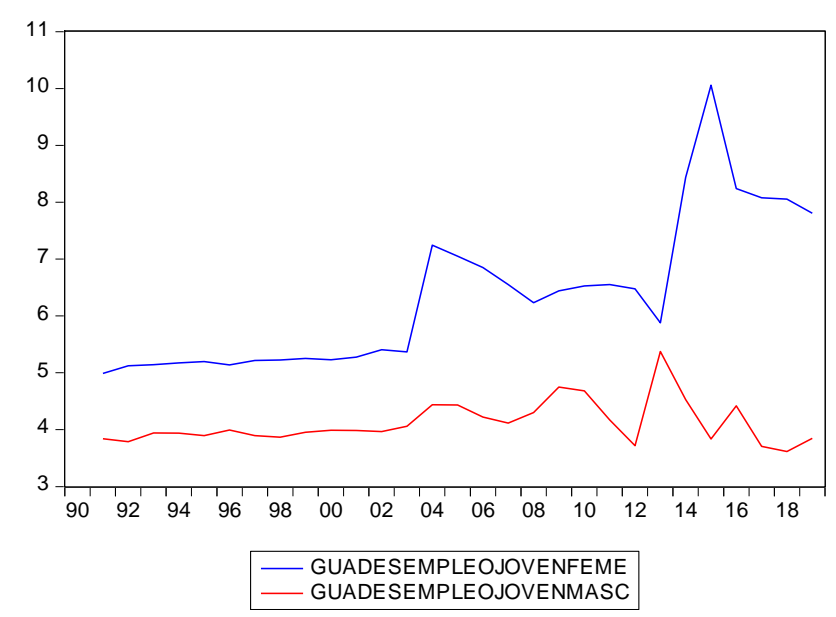

Figure 3. Female and Male youth unemployment rates

Equation (6) shows that the import tariff has a positive and significant coefficient, which represents evidence that openness has had negative impacts on domestic savings (Note 2); this result means that to higher protection there would correspond higher savings rates.

The above equations present evidence of the important role that female employment plays in mobilizing savings. Many theories have been postulated about the determinants of savings, standing out those related to the demoFigureic dependency rate, the interest rate, the "life cycle", money, and credit, among others. Given the results presented in table 2, it follows that quality female employment should be highlighted as an instrument for increasing savings.

The results also show that in Guatemala women constitute an important potential reservoir for mobilizing domestic savings and thus to impart dynamism to economic growth, which can be activated by promoting quality female employment and closing the employment gender gaps.

Given the above results, the question that arises is which variables have influenced the trajectory of the employment ratios. Figure 4 shows that the ratio of female to male industrial employment fell in the period as the import tariff, (Guatarifa), decreased, from a ratio of 1.17 in 1990 to 0.86 in 2017. 


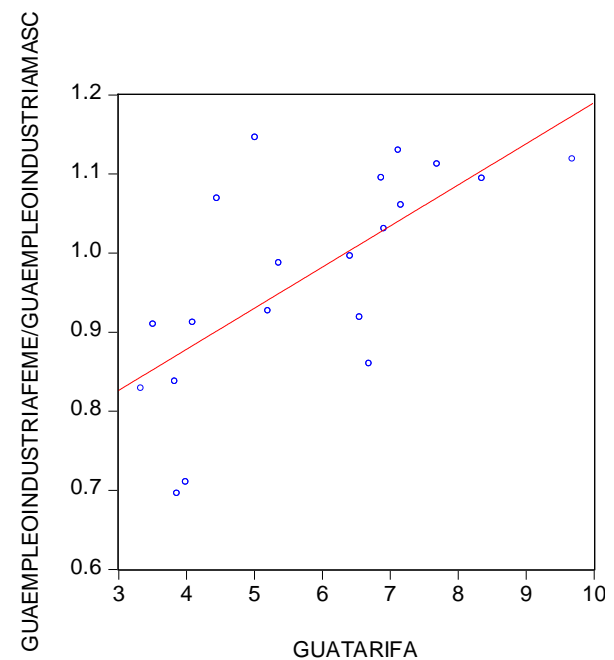

Figure 4. Tariff on imports and the ratio of female to male industrial employment

The ratio of female to male employment in the service sector fell in the same period, from 2.02 in 1990 to 1.89 in 2017. In contrast, the ratio of female to male self-employment increased from 1.28 to 1.39 in the period, indicating that trade liberalization has fueled the growth of the informal sector.

It follows, then, that the reduction of the external tariff has given rise to larger losses of female jobs relative to male in the industrial and services sectors, which explains the fall in domestic savings and the loss of dynamism that the Guatemalan economy has experienced in the last three decades.

\section{The Solow Economic Growth Model and Female Employment}

As is well known, in the Solow model of an open economy expresses the economic growth rate, $\mathrm{g}$, as:

$$
g=(1 / k)(s+h)
$$

Where $\mathrm{k}$ is the capital product ratio, $\mathrm{s}$ is the domestic savings rate and $\mathrm{h}$ is the external savings rate. Given the results shown in Table 2, which showed that domestic savings depends on the ratio of female to male employment, that is: $\mathrm{s}=\mathrm{f}$ (Ratio employment), it is valid to write the previous equation as follows:

$$
g=(1 / k)(\text { Ratio employment }, h)
$$

Figure 5 presents the variable Ratio Employment, (Ratio Empleo), on the abscissa, while the ordinate represents the economic growth rate, (Crecimiento Economico); this Figure indicates that economic growth results from combinations of values of $\mathrm{h}$ and the employment ratio (Note 3 ).

Initially, the growth rate is $\mathrm{g} 1$, resulting from external savings $\mathrm{h} 1$ and the employment ratio R1. It is assumed that the employment ratio does not increase after reaching R1, so higher growth rates will be possible only if external saving is increased. In Figure 5 it is observed that with R1 constant, the increase in external savings from $\mathrm{h} 1$ to h2 leads to increasing economic growth to $\mathrm{g} 2$.

The point to emphasize is that the growth rate $\mathrm{g} 2$ can be obtained by increasing $\mathrm{R} 1$ to $\mathrm{R} 2$, at the same value of external saving h1. The implication in this case is that the determining constraint to economic growth is the gap in the ratio of female to male employment, R2-R1. The implication is that in the practice and theory of macroeconomics the gender gap must receive the same attention given to other well known gaps.

This has implications on the convergence of incomes across countries, as their rate of economic growth is determined by the ratios of female to male employment; in the same vein, the "Middle Income Trap" may reflect a stagnant female employment vis a vis male employment. Another implication is the existence of large benefits that result from closing the gender participation gap to promote economic growth and solvency. 


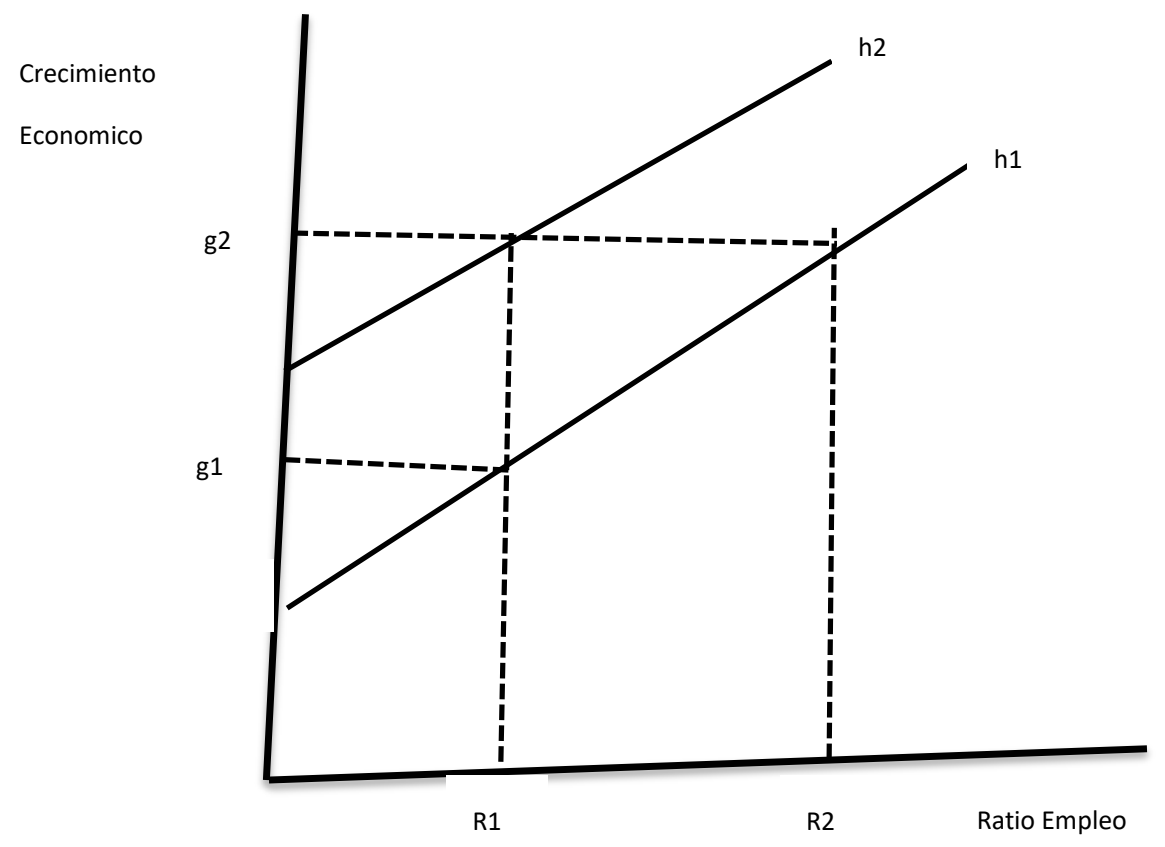

Figure 5. Ratio of Female to Male employment (Ratio Empleo) and economic growth (Crecimiento Economico)

\section{The Labor Market and the External Savings Gap}

This section investigates the role that the female to male employment ratio plays on the trade account deficit. This relationship is derived from the identity:

$$
\text { Trade account deficit }=\mathrm{M}-\mathrm{X}=\mathrm{I}-\mathrm{S}
$$

Where $\mathrm{M}=$ imports, $\mathrm{X}=$ exports, $\mathrm{I}=$ investment, and $\mathrm{S}=$ domestic savings, with all variables expressed as percentages of GDP. Since $\mathrm{S}$ is determined by the female to male employment ratio, the above expression can be written as:

Trade account deficit $=\mathrm{M}-\mathrm{X}=\mathrm{I}-$ Female /Male employment ratio

This expression indicates that there is a link between the external savings gap and the labor market or, in general terms, that said gap is associated with social policies related, among others, to public spending on education and health, to the promotion of gender equality, to increasing access to child care centers, and to the pension system, variables that determine the increase in female employment (Caceres, 2020c).

To verify the validity of the previous expression, several equations were estimated using employment ratios of various types, with the results shown in Table 3.

In all the equations estimated, the coefficients of the investment rate were positive and significant. Equation (1) in Table 3 shows that the coefficient of the ratio of female to male industrial employment is negative and significant, and the equation explains 80 percent of the variance of the trade account deficit. The equation indicates that if this ratio increased by 0.5 , which is equivalent to restoring its value to that of the early $1990 \mathrm{~s}$, the deficit in the trade account would fall by 7 percentage points.

In equation (2) in Table 3 it is observed that the coefficient of the ratio of female to male employment in the services sector is positive and significant, thus exercising the same role as the industrial employment ratio in reducing the deficit in the trade account.

On the contrary, the female to male self-employment ratio shows a positive and significant coefficient, (equation (3)), which highlights the role of informality in increasing the external savings gap; the implication is that the informal sector is a cause of instability in the external accounts, a point that has not received attention in the lietarature.

The coefficient of the agricultural employment ratio is negative and significant, as observed in equation (4). The coefficient of this ratio has the largest dimension of all the ratios, which shows the importance of agriculture in the determination of the external accounts, a point that has not received attention in the literature. 
Regarding the ratio of female to male youth unemployment, its coefficient is positive and significant, (equation 5, Table 3), which indicates that the increase in female youth unemployment relative to male youth unemployment contributes to increase the deficit in the trade account. Given the high values and instability of female youth unemployment, it follows that youth unemployment may impart volatility to the external accounts. This can create a vicious cycle in which the increase in female youth unemployment leads to growing deficits in the trade account, which can lead to restrictive measures on economic activity, such as increasing interest rates, leading to a new round of increases in youth unemployment.

In equation 6 it is observed that the tariff has a negative and significant coefficient, and the equation explains 77 percent of the variance of the trade deficit. If the tariff were reestablished to its 1997 value of 8.80 percent, the trade deficit would fall by 8 percentage points. This result is in agreement with an extensive literature that has presented evidence that the most salient result of the trade liberalization reforms has been the large increases in the deficits in the trade account (Stiglitz, 2000, 2002; Santos, 2000; Santos \& Thirlwall, 2004).

It can be deduced that the magnitude and the type of female employment have impacts on the external indebtedness and solvency of a country, since high deficits in the trade account imply that its financing will require greater amounts of external resources, which may have adverse repercussions on external debt and on the external solvency of the country.

The implication is that social policy is a means of stabilizing the external sector. In other words, social policy establishes a link between the labor market and the balance of payments, insofar as the increase in female relative to male employment contributes to the reduction of trade deficits. Another implication is that the gender employment gap determines the external accounts and, in particular, undermines the solvency of a country.

Table 3. External gap and the labor market (Dependent Variable: Imports Minus Exports (\% of GDP))

\begin{tabular}{|c|c|c|c|c|c|c|}
\hline \multirow{2}{*}{ Independent variables } & \multicolumn{6}{|c|}{ Equation number: } \\
\hline & (1) & (2) & (3) & $(4)$ & $(5)$ & (6) \\
\hline \multirow[t]{2}{*}{ Constant } & 7.0074 & 33.5965 & -44.423 & 4.1311 & 16.0678 & -2.755 \\
\hline & $(3.08)$ & $(3.20)$ & $(2.30)$ & $(2.23)$ & $(4.32)$ & $(5.51)$ \\
\hline \multirow[t]{2}{*}{ Cuali } & 2.3995 & & 1.2268 & 3.9568 & 3.4257 & \\
\hline & $(3.53)$ & & $(5.73)$ & $(6.10)$ & (3.24) & \\
\hline \multirow[t]{2}{*}{ Investment } & 1.0276 & 0.9726 & 1.2268 & 1.4581 & 1.1604 & 1.3041 \\
\hline & (11.68) & $(6.15)$ & $(5.73)$ & (12.44) & $(4.70)$ & $(8.82)$ \\
\hline Female industrial employment/ & -13.8003 & & & & & \\
\hline Male industrial employment & $(6.60)$ & & & & & \\
\hline Female services employment/ & & -19.7108 & & & & \\
\hline ale services employment & & $(3.66)$ & & & & \\
\hline Female self-employment/ & & & 26.2485 & & & \\
\hline Male self-employment & & & $(2.00)$ & & & \\
\hline Female agricultural employment/ & & & & -58.0165 & & \\
\hline Male agricultural employment & & & & $(7.70)$ & & \\
\hline Female youth unemployment/ & & & & & 4.5924 & \\
\hline Male youth unemployment & & & & & $(3.54)$ & \\
\hline \multirow[t]{2}{*}{ Tariff } & & & & & & -1.3723 \\
\hline & & & & & & $(4.70)$ \\
\hline R square & 0.80 & 0.71 & 0.60 & 0.80 & 0.71 & 0.77 \\
\hline
\end{tabular}

\section{Economic growth Constrained by the Balance of Payments and the Labor Market.}

Based on the results obtained in the preceding sections, it is possible to rework the well-known Thirlwall (1979) model of economic growth restricted by the balance of payments, in terms of the restriction imposed by low female employment.

Starting from the the identity:

$$
\mathrm{M}-\mathrm{X}=\mathrm{I}-\mathrm{S}=\mathrm{I}-\mathrm{a} \text { (Ratio Employment) }
$$

The equilibrium of the balance of payments implies that:

$$
\mathrm{M}-\mathrm{X}=0 \text {, so } \mathrm{I}=\mathrm{a} \text { (Ratio Employment) }
$$


Given that $\mathrm{I}=\mathrm{k}(\mathrm{g})$, where $\mathrm{k}$ is the capital-output ratio and $\mathrm{g}$ is the rate of economic growth, the growth rate that is determined by the balance of payments constraint is:

$$
\mathrm{g}=(\mathrm{a} / \mathrm{k})(\text { Ratio Employment })
$$

Introducing Guatemala's female to male employment ratios in the industrial, agricultural, services, and self-employment sectors, the equation above can be written as:

$\mathrm{g}=(1 / \mathrm{k})($ w1a1Ratio industrial $+\mathrm{w} 2 \mathrm{a} 2$ Ratio services $+w 3 \mathrm{a} 3$ Ratio agricultural

- w4a4Ratio self-employment)

Where w1, w2, w3, and w4 represent the share of the specific type of employment in total employment; Ratio industrial, Ratio services, Ratio agricultural and Ratio self-employment, mean the ratios of female to male employment in those sectors, and a1, a2, a3, and a4 represent the propensities to save related to the respective type of employment, obtained from table 3.

An equation was estimated to express the rate of economic growth in terms of the investment rate, which resulted in a value of $k$ of 4.5 . Equations (1), (2), (3), and (4) in table 2 show that the propensities to save are:

a1 $=17.88 \quad$ a2 $=26.23 \quad$ a3 $=40.07 \quad$ a4 $=-20.82$

And the weights of female employment to total female employment in the different sectors are:

$\mathrm{w} 1=0.15, \mathrm{w} 2=0.35, \mathrm{w} 3=0.05$ and $\mathrm{w} 4=0.45$

It is then obtained that the economic growth rate determined by the balance of payments is:

$\mathrm{g}=3.46$ Ratio Industrial + 9.18 Ratio Services + 2.00 Ratio Agricultural - 9.37 Ratio Self-employment

Computing the value of $g$ shown above with Ratio data corresponding to 2018 , results in a rate of economic growth equal to 5.27.

This is the growth rate that guarantees that $\mathrm{M}=\mathrm{X}$, that is to say, that the trade account is balanced. This rate will tend to be low to the extent that the informal sector is large.

\section{The Index of Gender Inequality and the Model of Growth Constrained by the Balance of Payments}

The gender inequality index, IDG, represents the weighted disparities between men and women in three areas: labor participation, health, and political participation. It has a negative correlation with the domestic savings rate as shown in in Figure 6 using 2017 data from a cross-section of 13 Latin American countries.

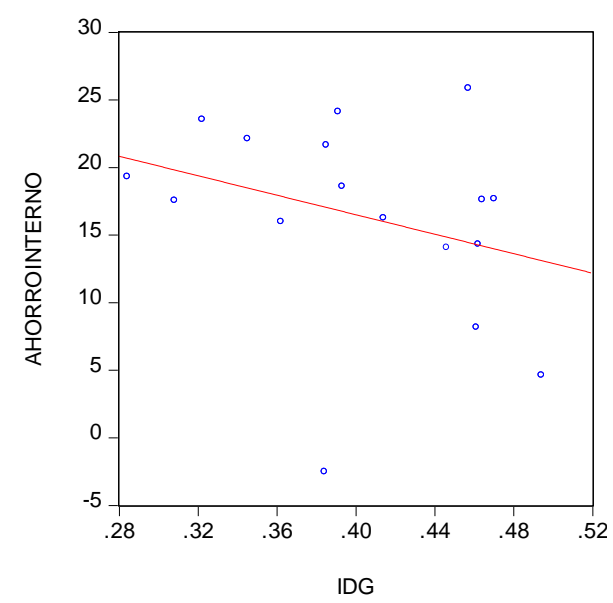

Figure 6. GDI and domestic savings rate

The equation corresponding to this Figure is shown below, where CualiES is a qualitative variable that represents the case of El Salvador:

Domestic savings $=39.6230-23.3428$ CualiES -55.4268 IDG

R squared $=0.53$

The savings rate can be written as:

$\mathrm{S}=\mathrm{c}-\mathrm{vIDG}$, where $\mathrm{c}=39.6230$ and $\mathrm{v}=55.4268$ 
Since $\mathrm{I}=\mathrm{kg}$, the economic growth rate compatible with the balance of payments equilibrium is:

$\mathrm{M}-\mathrm{X}=\mathrm{kg}-\mathrm{c}+\mathrm{vIDG}=0$

Hence, the economic growth rate is given by:

$\mathrm{g}=(1 / \mathrm{k})(\mathrm{c}-\mathrm{vIDG})$

The increase in the growth rate due to a reduction of the IDG is:

$\mathrm{D}(\mathrm{g})=(1 / \mathrm{k}) \mathrm{vD}(\mathrm{IDG})$,

$=14.3 \mathrm{D}(\mathrm{GDI})$

where $\mathrm{D}$ is the difference operator.

Guatemala's gender inequality index was 0.492 in 2018, the highest in Latin America; if this value fell to the level of El Salvador's value of 0.397, the increase in the growth rate would be $14.3(0.095)=1.3$ percentage point. The implication is that discrimination against women lowers the rate of economic growth.

\section{The Thirlwall Model, Gender and the Labor Market}

In its simplest version, Thirlwall (197) model rests on an equation for determining the imports of a given country:

$\log (M)=c+b \log (Y)$, where $b$ is the income elasticity of imports, and $\mathrm{c}$ is a constant.

From this equation the rate of growth of imports, $\mathrm{m}$, is given by the expression:

$\mathrm{m}=$ by, where $\mathrm{y}$ is the rate of economic growth.

The equilibrium of the balance of payments implies that the growth of imports be equal to the growth of imports, $\mathrm{m}=\mathrm{x}$, where $\mathrm{x}$ is the growth rate of exports; and thus: $\mathrm{y}=\mathrm{x} / \mathrm{b}$.

This model assumes that the elasticity of imports is the same for all imported goods, and all people's incomes. But it is valid to assume that the magnitude of this elasticity depends on the nature of personal income, whether the person is female or male, and other variables. For example, in countries with a high concentration of income distribution, the income elasticity of imports will tend to be high due to the high percentages of manufactured and luxury goods that would be imported. On the contrary, in countries with a high ratio of female to male quality employment, imports would tend to be low since women would import consumer goods for use in the family, goods that have low income elasticity.

It is expected that the ratio of industrial female employment to male employment in the same sector has an impact on the import income elasticity. It should be noted that in Guatemala the ratio of imports to GDP falls as this ratio increases, as shown in Figure 8; this indicates that female industrial employment is reflected in the import income elasticity, so that the promotion of female quality employment can be seen as a "protectionist" policy. Given that female employment protects the economy from imports, it represents a means to prevent deindustrialization.

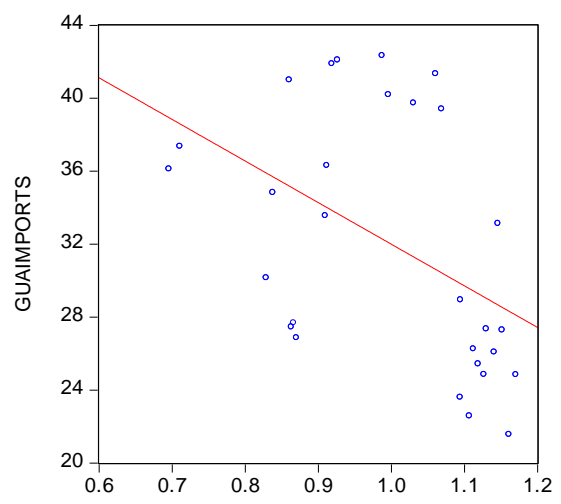

GUAEMPLEOINDUSTRIAFEME/GUAEMPLEOINDUSTRIAMASC

Figure 8. Female to male employment ratio in the industrial sector and the share of imports in GDP

It is proposed that the equation that determines imports is the following:

$\log (\mathrm{M})=\mathrm{o}+\mathrm{p}((1 /$ Ratio employment $) \log (\mathrm{Y}))$, which implies that as the ratio of female to male industrial employment increases, the income elasticity of imports will be lower. 
In terms of growth rates, the expression for $\mathrm{m}$, the rate of growth of imports is:

$\mathrm{m}=(\mathrm{p} /$ Ratio employment $) \mathrm{y}$

The equilibrium of the trade account implies that $\mathrm{m}=\mathrm{x}$, where $\mathrm{x}$ is the rate of growth of imports.

Thus, the rate of economic growth is:

$\mathrm{y}=\mathrm{x} /(\mathrm{p} /$ Ratio employment $)$

Equations were estimated using different sectorial female to male employment ratios as independent variables, with the results shown in Table 4.

Table 4 shows that the ratios of the different types of employment have positive and significant coefficients.

Table 4. Determination of imports (Dependent variable: Log(Imports))

\begin{tabular}{|c|c|c|c|c|}
\hline \multirow{2}{*}{ Independent Variables } & \multicolumn{4}{|c|}{ Equation number: } \\
\hline & $(1)$ & $(2)$ & (3) & $(4)$ \\
\hline \multirow[t]{2}{*}{ Constant } & 7.2337 & -3.1006 & 4.3139 & 7.8899 \\
\hline & (18.63) & $(3.20)$ & $(4.30)$ & $(1.48)$ \\
\hline \multirow[t]{2}{*}{ (1/Ratio industrial) $\log (\mathrm{Y})$} & 0.2031 & & & \\
\hline & $(5.71)$ & & & \\
\hline \multirow{2}{*}{ (1/Ratio self) $\log (Y)$} & & 1.2014 & & \\
\hline & & (12.97) & & \\
\hline \multirow[t]{2}{*}{ (1/Ratioservices) $\log (\mathrm{Y})$} & & & 0.9686 & \\
\hline & & & $(5.32)$ & \\
\hline \multirow[t]{2}{*}{ (1/Ratioagricultural) $\log (\mathrm{Y})$} & & & & 0.0481 \\
\hline & & & & $(4.36)$ \\
\hline $\mathrm{R}$ squared & 0.52 & 0.88 & 0.51 & 0.51 \\
\hline
\end{tabular}

The total income elasticity of imports is obtained by calculating the sum of the coefficient $\mathrm{p}$ weighted by the weights of the sectors in total female employment, w, and divided by the corresponding Ratio employment:

Elasticity $=\mathrm{J}$ (piwi/Ratio employmenti), where $\mathrm{J}$ is the summation sign,

and $\mathrm{y}=\mathrm{x} /$ Elasticity

It can be seen in the expression above that the higher the female to male employment ratio is the lower will be the income import elasticity. The implication is that the balance of payments constraint can be overcome by increasing female employment. In other words, the external constraint can be viewed as a reflection of the workings of the labor market and, in particular, as a reflection of discrimination that women suffer in the workplace.

The sectoral contributions to the income elasticity of imports are as follows:

Industrial: $(0.2031)(0.15) / 0.87=0.0350$

Services $=((0.9686)(0.35) /(1.89)=0.1793$

Agricultural $=(0.0481)(0.05) / 0.23=0.0104$

Self-employment $=(1.2014)(0.45) / 1.40=0.3862$

Thus, the total import elasticity is equal to 0.6112

The average value of the elasticity in the $1990-2018$ period is 0.84

\section{Cointegration of Female to Male Employment Ratios}

The above results have regional implications. It should be noted that there is evidence that the existence of cointegration between the rate of economic growth and the rate of growth of exports in a given country is an indication of the existence of a growth regime restricted by the balance of payments, which has been demonstrated in the case of several countries: the USA by Atesoglu (1997) and by Hieke (1994); Argentina (Chena, 2010); South Africa (Ozturk \&Acarovci, 2010); Brazil (Bertola, Higuchi, \& Porcile, 2000); and by Holland, Vilela Viera and Canuto (2014) for the case of 10 Latin American countries.

Caceres (2020c) has shown in the framework of an economic integration scheme among developing countries, that the economic growth model constrained by the balance of payments of a given country is determined by the 
growth rates of the other member countries, and that there exist cointegration relationships among the member countries' growth rates. Hence, the existence of cointegation among the ratios of member countries' female to male employment indicates that that the balance of payments constraint on economic growth results from female employment gaps.

In the case of three Central American countries, Guatemala, El Salvador, and Honduras, which have the strongest commercial ties in Central America, the economic growth rate of Guatemala, gGUA is given by:

$\mathrm{gGUA}=\mathrm{A} 0+\mathrm{A} 1 \mathrm{gES}+\mathrm{A} 2 \mathrm{gHO}$

where ES and HO represent the cases of El Salvador and Honduras.

In view that these growth rates are determined by the ratio of female to male employment, of various types, this equation can be written as follows:

Ratio Employment GUA = Ratio employment ES + Ratio employment HO

Unit root tests indicated that these ratios were integrated of order one; cointegration tests were carried out with results that indicated the existence of one cointegration vector among these variables as can be seen in Table 5 . The existence of cointegration means that the three countries' industrial employment ratios are interdependent, meaning that they have a regional character.

Table 5. Cointegration test of female to male industrial employment ratios

\begin{tabular}{ccccc}
\hline \multicolumn{2}{l}{ Unrestricted Cointegration Rank Test (Trace) } & Trace & 0.05 & \\
\hline Hypothesized & & Statistic & Critical Value & Prob.** \\
\hline No. of CE(s) & Eigenvalue & 41.17145 & 29.79707 & 0.0016 \\
None ${ }^{*}$ & 0.650928 & 13.80704 & 15.49471 & 0.0884 \\
At most 1 & 0.374227 & 1.619071 & 3.841466 & 0.2032 \\
At most 2 & 0.060373 & &
\end{tabular}

Trace test indicates 1 cointegrating eqn(s) at the 0.05 level

A cointegration test was carried out for the series of female to male self employment ratios of the three countries (Table 6), with results that indicated that there was no cointegration vector; this means that informality is a national phenomenon, without spillovers to the regional field.

Table 6. Cointegration test of self-employment ratios (female to male)

\begin{tabular}{|c|c|c|c|c|}
\hline \multicolumn{5}{|c|}{ Unrestricted Cointegration Rank Test (Trace) } \\
\hline Hypothesized & & Trace & 0.05 & \\
\hline No. of CE(s) & Eigenvalue & Statistic & Critical Value & Prob.** \\
\hline None & 0.415121 & 23.03520 & 29.79707 & 0.2443 \\
\hline At most 1 & 0.294743 & 9.090105 & 15.49471 & 0.3571 \\
\hline At most 2 & 0.000426 & 0.011083 & 3.841466 & 0.9159 \\
\hline
\end{tabular}

Trace test indicates no cointegration at the 0.05 level

Given that the female to male employment ratios determine economic growth, which in turn determines the magnitude of trade flows between Central American countries, these results indicate that economic integration gains strength to the extent that quality female employment increases relative to male employment in the member countries. This topic is absent in the theory of economic integration.

\section{The Feldstein and Horioka Paradox}

Mention should be made of what has been called the Feldstein and Horioka paradox, which refers to the high correlations between investment and domestic savings in developed and developing countries. This is contrary to the postulate of the neoclassical model that in an open economy this correlation would not exist due to capital mobility (Note 4).

Below is evidence that there is a close relationship between investment and the ratio of total female to total male employment. The estimated equation for the period 2000-2019 is the following:

Investment $=1.5278+26.8919$ Female employment/Male employment

R squared $=0.67$ 
Furthermore, there is a close relationship between the investment rate and the ratio of female to male agricultural employment (Note 5):

Investment $=2.0107+45.9531$ Female agricultural employment/Male agricultural employment

R squared $=0.38$

It is worth highlighting the result that the ratios of female to male self-employment has a negative coefficient, which means that informality has adverse repercussions on investment:

Investment $=7.3841-44.0545$ Female self employment/Male self-employment

R squared $=0.25$

This result means that there exists capital mobility in the informal sector, with capital coming from the formal sector, as a result of the poverty prevailing in the informal sector.

Of relevance is the result that the coefficient of the ratio of female to male youth unemployment with lags of 7 years has a negative sign:

Investment $=45.2150-20.1225$ Female youth unemployment $(-7) /$ Male youth unemployment $(-7)$

R squared $=0.40$

This result denotes that unemployed youth do transition to informality. This is another manner in which youth unemployment exerts negative repercussions on economic growth.

\section{How to Increase the Female to Male Employment Ratio}

At this point, the topic of interest is to identify the variables that lead to increases in the female to male employment ratio. Recent literature, particularly from the World Bank (World Bank, 2016) and the ILO (Heintz, 2006), has presented interesting proposals on policies to promote female employment,

It is argued in the following paraFigures that social mobility can be a valuable mechanism to promote female labor market participation. The Human Opportunity Index, IOH, designed by the World Bank (Molinas et al., 2011), represents the degree in which girls and boys have access to the services of education, health, electricity, housing, potable water, and to finish the sixth grade in the reglementary time, independently of their place of residence and of the income of their parents. This Index has been interpreted as a measure of social mobility existing in the respective country.

Figure 9 constructed with a cross-section of 2017 data of Latin American countries, shows that as the human opportunity index, IOH, increases, the ratio of female to male employment increases; in other words, investments in health, education, housing, and electricity, that serve girls and children regardless of their parents' income and their place of residence, is a means to promote social mobility and female participation. Caceres (2013) has shown that in Latin American countries the human opportunity index increases with the increase in social spending, particularly spending on education. This highlights the role of social policy in increasing economic growth and external solvency, which indicates that social policy must receive the same, or more, attention than that given to traditional macroeconomic policies.

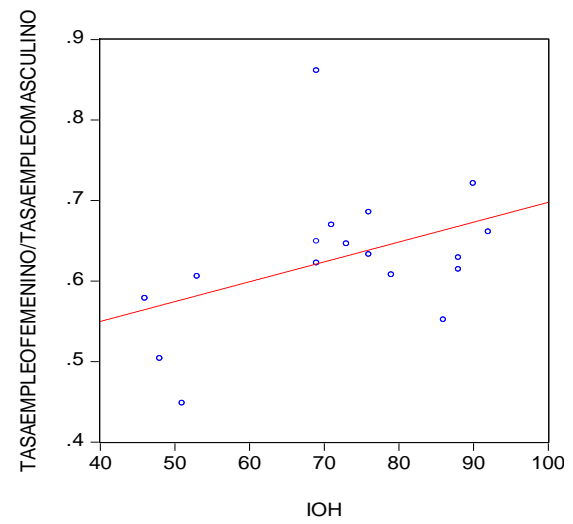

Figure 9. Human opportunity index and female to male employment ratio 
Moreover, the closing of the gender employment gap demands solid institutions (Caceres, 2015). Figure 10 shows that the ratio of female to male employment increases with the Latin American countries' rule of law, (estadoderecho), indexes, implying that the increase of the employment ratio requires strengthening national institutions. Caceres (2015) has also shown that the rule of law index increases with the average years of schooling in the respective Latin American country and with public spending on education, and that a rule of law gap can be more determining in undermining economic growth than the domestic and external savings gaps.

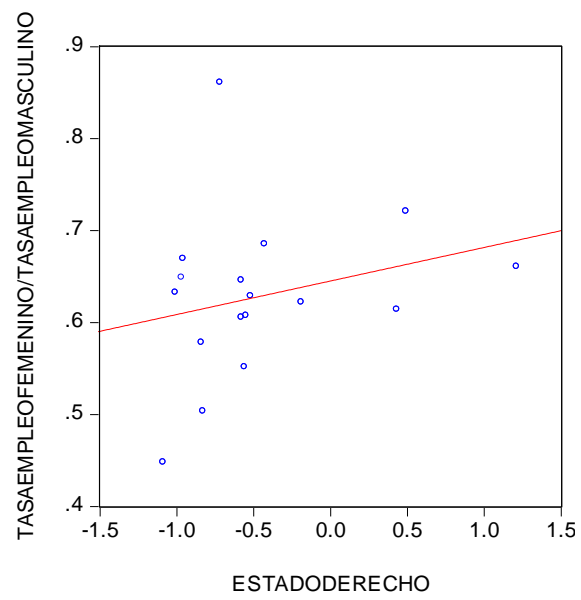

Figure 10. Index of the rule of law and female to male employment ratio

Reference should be made to table 6 that shows the total female to male employment ratios in Latin American countries in 2017. The lowest value corresponds to Guatemala, but in general, almost all the countries have low values, especially the Central American countries. This table shows that there is an immense potential to boost economic growth through support for female employment (Note 6). This is of importance given the ravages of the COVID19 pandemic that can be expected to depress world trade for several years; hence female employment can be a means to counteract the resulting recessive tendencies.

Table 7. Female to male employment ratios in 2017

\begin{tabular}{lc}
\hline Chile & 0.661169 \\
Argentina & 0.628869 \\
Uruguay & 0.721228 \\
Panama & 0.622367 \\
Costa Rica & 0.614318 \\
Mexico & 0.55181 \\
Brazil & 0.685429 \\
Peru & 0.861162 \\
Ecuador & 0.632842 \\
Colombia & 0.607716 \\
R. Dominicana & 0.646338 \\
Paraguay & 0.669524 \\
El Salvador & 0.605698 \\
Nicaragua & 0.578602 \\
Guatemala & 0.448317 \\
Honduras & 0.503922 \\
Bolivia & 0.649247 \\
\hline
\end{tabular}

\section{Conclusions}

About the first research point, whether the female to male employment ratio has an impact on domestic savings, the answer is positive when it comes to industrial, agricultural, and service sector employment, and negative when it comes to self-employment. Given the determining role of saving on economic growth, (Misztl, 2011; Karahan, 2018; Esso et al., 2016), these results show that there are important links between the labor market, gender, and economic development. This underscores the importance of incorporating gender in macroeconomic 
analysis, especially in studies on the determination of savings, which have traditionally relied on variables such as the money market, demoFigureic dependence, and the life cycle.

By not taking gender aspects into account in empirical savings studies, the estimated savings equations may have specification errors.

With respect to the simplest expression of the Solow economic growth model, the female to male employment ratio was incorporated into this model to argue that economic growth can be restricted by a female employment gap.

Regarding the postulate that the increase of the female to male employment ratio reduces the external savings gap, the results show that this is the case for the employment ratios in the industrial, agricultural, and services sectors, and the opposite occurs in the case of self-employment, as well as when it comes to the ratio of female to male youth unemployment.

This can be interpreted as evidence that the external savings gap is a manifestation of the female employment gap or, as well, an excess of female youth unemployment relative to male youth unemployment. An implication is that policies that encourage female employment, such as investing in child care centers, constitute macroprudential policies that generate stability to the external accounts; the World Bank (2016) has shown that the expansion of child care centers in Chile led to a significant increase in GDP growth.

Of special importance is that the female to male employment ratios determine the income elasticity of imports, which shows that this elasticity reflects, or is the result of the economic structure of the country in question, as well as of the distribution of female employment across sectors and, therefore, is related to social policy. In other words, the ratio of female to male employment is endogenous to economic and social structures, and thus economic growth is endogenous to social policies and, as well, to a "culture" that inhibits the participation of women in the labor market.

It is necessary to emphasize the role of the female to male employment ratio in reducing the external gap, which shows that female employment is an instrument of macroeconomic stabilization and that it has implications in the prevention of external debt crisis. It follows that countries with low rates of female employment will tend to have higher rates of macroeconomic instability. Cáceres (2020a) has presented evidence for Latin American countries that the gender inequality index, GDI, has a negative association with the amounts of international reserves per capita of the respective country. In other words, gender equality offers the domestic economy a "shield" against the vicissitudes of the international economy (Note 7).

The results have shown the existence of an important engine of economic growth that lies unused, which is female employment that, in the face of the global pandemic, should be activated so that women play the significant role of true Tigers in the economic and social development of Latin America.

\section{References}

Agenor, P. R., Ozdemir, K., \& Pinto, M. E. (2018). Gender Gaps in the Labor Market an Economic Growth. World Bank, working paper 8661, Washington DC, 2018. https://doi.org/10.1596/1813-9450-8661

Angelucci, M. (2007). Love on the Rocks: Alcohol Abuse and Domestic Violence in Rural Mexico. IZA Discussion Paper no. 2706. https://doi.org/10.2202/1935-1682.1766

Atesoglu, H. (1997). Balance-of-Payments-Constrained Growth Model and its Implications for the United States. Journal of Post Keynesian Economics, (19), 327-335. https://doi.org/10.1080/01603477.1997.11490114

Ayres, R. L. (1998). Crime and Violence as Development Issues in Latin America and the Caribbean. World Bank, Washington DC. https://doi.org/10.1596/0-8213-4163-4

Bertola, L., Higachi, H., \& Porcile, G. (2002). Balance-of-Payments-Constrained Growth in Brazil: A Test of Thirlwall, 1890-1973. Journal of Post Keynesian Economics, (25), 123-140. https://doi.org/10.1080/01603477.2002.11051348

Caceres, L. R. (2013). Labor Market Participation in Latin America, 2000-2008. Journal of Developing Areas. (47), 241-261. https://doi.org/10.1353/jda.2013.0011

Caceres, L. R. (2015). Financing Investment in Sub-Saharan Africa: Savings, Human Development, or Institutions? Journal of Developing Areas, (49), 1-23. https://doi.org/10.1353/jda.2015.0122

Caceres, L. R. (2020a). Genero y Ahorro Interno en America Latina. Mexican Journal of Economics and Finance.

Caceres, L. R. (2020b). Genero, Apertura y Ahorro Domestico en Honduras. Unpublished paper. 
CEPAL. (2018). La Ineficiencia de la Desigualdad.

Chena, P. I. (2014). Balance-of Payments-Constrained Growth in Argentina (1976-2006). Journal of Post Keynesian Economics, (36), 699-716. https://doi.org/10.2753/PKE0160-3477360406

David, A., Goncalves, A. E., \& Werner, A. (2020). Reexamining the National Savings-Investment Nexus Across Time and Countries. IMF working paper 20/124. https://doi.org/10.5089/9781513548579.001

Esso, L. J., \& Keho, Y. (2010). The Savings-Investment Relationship: Cointegration and Causality Evidence from Uemoa Countries. International Journal of Economics and Finance, (2), 174-180. https://doi.org/10.5539/ijef.v2n1p174

Heintz, J. (2006). Globalization, Economic Policy and Employment: Poverty and Gender Implications. ILO.

Hieke, H. (2006). Balance of Payments Constrained Growth: A Reconsideration of the Evidence for the US Economy. Journal of Post Keynesian Economics, (19), 313-325. https://doi.org/10.1080/01603477.1997.11490113

Hinz, R., McCarthy, D., \& Turner, J. (1996). Are Women Conservative Investors?: Gender Differences in Participant-Directed Pension Investments. In M. Gordon, O. Mitchell, \& M. Twinney (Eds.), Positioning Pensions for the Twenty-First Century (pp. 145-156). University of Pennsylvania Press, Philadelphia, PA.

Holland, M., Vilela, V. F., \& Canuto, O.(2004). Economic Growth and the Balance of Payments Constraint in Latin America. Investigacion Economica, (63), 45-74.

Kumar, S. (1978). Role of the Household Economy in Child Nutrition at Low Incomes: A Case Study in Kerala. Occasional Paper No. 95, Department of Agricultural Economics, Cornell University, Ithaca, NY.

Misztal, P. (2011). The Relationship Between Saving and Economic Growth in Countries with Different Levels of Development. The Central European Journal of Social Sciences and Humanities, (7), 17-29.

Molinas, V. J., Paes de Barros, R., Saavedra, J., Giugale, M., Cord, L., Pessino, C., \& Hasan, A. (2011). Do Our Children Have a Chance? World Bank. https://doi.org/10.1596/978-0-8213-8699-6

Patra, S. K., \& Sofi, A. S. (2016). Causal Nexus Between Growth and Savings in India Using Nonlinear Causality Approach. International Journal of Research \& Methodology in Social Science, (2), 6-18.

Rodgers, J. R. (1994). Female-Headed Families: Why are They So Poor? Review of Social Economy. https://doi.org/10.1080/758519572

Santos, P. A. (2002). The Effects of Trade Liberalization in Imports in Selected Countries. World Development, (30). https://doi.org/10.1016/S0305-750X(02)00014-1

Santos, P. A., \& Thirlwall, A. P. (2004). The Impact of Trade Liberalization on Export Growth, the Balance of Trade and the Balance of Payments in Developing Countries. The Economic Journal, (114). https://doi.org/10.1111/j.0013-0133.2004.00187.x

Seguino, S., \& Floro, M. S. (2003). Does Gender have any Effect on Aggregate Saving? International Review of Applied Economics, (17), 47-166. https://doi.org/10.1080/0269217032000064026

Thirlwall, A. (1979). The Balance of Payments Constraint as an Explanation of International Growth Differences. Banca Nazionale del Lavoro Quarterly Review, (128).

Thomas, D. (1992). The Distribution of Income and Expenditure Within the Household. IFPRI World Bank Conference on Intrahousehold Resource Allocation: Policy Issues and Research Methods, Washington D.C.

World Bank. (2010). Vietnam: Country Gender Assessment.

World Bank. (2016). World Bank Gender Strategy.

\section{Notes}

Note 1. In this table, and in others, Cuali is a qualitative variable that represents the years of the global crisis, 2008-2012.

Note 2. The tariff rate data corresponds to the period 1997-2017.

Note 3. In this Figure it is assumed that the employment ratio and $\mathrm{h}$ have been divided by $\mathrm{k}$.

Note 4. See the review of the literature and recent analysis of this paradox in David, Goncalves y Werner (2020).

Note 5. This and the following three equations were estimated with data from 1990-2018. 
Note 6. These ratios substantially differ from the ratios existing in Vietnam, the country that is called nowadays the new Asian Miracle. According to World Bank (2010) data, in 2010 Vietnam's female and male participation rates were 81 and 72 per cent respectively, yielding an employment ratio of 89 per cent.

Note 7. The equation estimated by Cáceres (2020a) is:

Per capita reserves $=5926.747-11788.88$ GDI

R squared $=0.45$

\section{Copyrights}

Copyright for this article is retained by the author(s), with first publication rights granted to the journal.

This is an open-access article distributed under the terms and conditions of the Creative Commons Attribution license (http://creativecommons.org/licenses/by/4.0/). 